\title{
STAN OBECNY I MOŻLIWOŚCI ZAGOSPODAROWANIA REKREACYJNEGO WYBRANYCH „ŁÓDZKICH GÓR”1
}

\begin{abstract}
Abstrakt: Rekreacja mieszkańców jest istotną częścią życia w dużym mieście, jest to element konieczny przy wysokiej aktywności zawodowej lub naukowej społeczeństwa. Odpowiedni poziom zagospodarowania rekreacyjnego i sportowego obszarów publicznych znacznie zwiększa komfort życia miejskiego. Autorzy artykułu podjęli próbę zbadania i opisania możliwości wykorzystania na potrzeby rekreacji wzniesień znajdujących się na terenie Łodzi. Uwzględniono również stan infrastruktury umożliwiającej mieszkańcom aktywny wypoczynek na omawianych obszarach. W ramach badań przeprowadzono sondaż ankietowy określający znajomość „gór” wśród studentów kierunku „turystyka i rekreacja” Uniwersytetu Łódzkiego oraz inwentaryzację wybranych łódzkich wzniesień.

Słowa kluczowe: rekreacja, tereny zielone i wzniesienia w Łodzi, parki w Łodzi, zagospodarowanie rekreacyjne, łódzkie wzniesienia.
\end{abstract}

\section{THE CURRENT STATE AND PERSPECTIVES OF RECREATIONAL DEVELOPMENT, ON THE EXAMPLE OF SELECTED "ŁÓDŹ MOUNTAINS"}

Abstract: The purpose of the article was to determine what are the possibilities of utilisation hills in Eódź for recreation, taking into account the current state of their development. To evaluate the state of current infrastructure and to estimate the possibilities of developement of the hills, authors carried out inventory of the hills. The authors additionally conducted surveys among students of tourism and recreation of the University of Lodz to determine their knowledge about Łódź's hills. After the research and analysis of the literature, the authors agreed that recreational development of green areas, especially the hills in Łódź, is insufficient. Most often, the hills are frequented by residents of the nearest and neighboring housing estates. The reason for not using hills for recreational purposes is related to insufficient infrastructure and ignorance of residents about such places to rest.

Keywords: recreation, green areas and hills in Łódź, parks in Łódź, recreational infrastructure, hills developement.

\section{WPROWADZENIE}

Terenami zieleni miejskiej w Łodzi o najwyższych walorach przyrodniczych i krajobrazowych są parki, które zajmując powierzchnię ponad 600 ha stanowią prawie 30\% ich ogółu (dane z 2005 r.). Pozostałymi obszarami wchodzącymi w skład zieleni miejskiej są: zieleńce, zieleń osiedlowa, uliczna, zieleń w Ogrodzie Botanicznym i zoo, ogrody działkowe, cmentarze oraz ośrodki sportu i rekreacji (Studium uwarunkowań $i$ kierunków zagospodarowania przestrzennego miasta Łodzi 2010). Tak duża ilość terenów zielonych w mieście powinna sprzyjać rozwojowi rekreacji, niestety nie są one w pełni wykorzystywane. Problem niewykorzystanego potencjału terenów rekreacyjnych w Łodzi pojawia się w literaturze oraz został zaobserwowany przez autorów podczas przeprowadzania badań dotyczących zagospodarowania wybranych łódzkich wzniesień. W tym świetle ważne jest omówienie terenów rekreacyjnych, jakimi są łódzkie wzniesienia oraz ich zagospodarowania rekreacyjnego. Autorzy podjęli się próby zbadania obecnego stanu wzniesień oraz oceny możliwości wykorzystania „łódzkich gór” na potrzeby rekreacji mieszkańców.

\section{PROBLEM BADAWCZY W ŚWIETLE LITERATURY}

Artykuł ma na celu określenie, jakie są możliwości wykorzystania "łódzkich gór" do rekreacji z uwzględnieniem aktualnego stanu ich zagospodarowania. Osiągnięcie celu miały zapewnić przeprowadzone przez autorów badania ankietowe oraz inwentaryzacja. Autorzy podjęli się zbadania omawianego proble$\mathrm{mu}$, ponieważ nie istnieje kompleksowa praca traktująca o rekreacji na terenie łódzkich wzniesień.

Pozycją, która najszerzej i najdokładniej opisuje stan oraz plany rozwoju zagospodarowania rekreacyjnego w Łodzi jest publikacja Zagospodarowanie terenów rekreacyjnych Łodzi. Plan, perspektywy autorstwa J. JAKÓBCZYK-GRYSZKIEWICZ, W. DYBY, SZ. MARCIŃCZAKA oraz S. TANASIA (2008). Autorzy zbadali zagospodarowanie rekreacyjne zarówno terenów naturalnych, jak i obiektów rekreacyjnych znajdujących się w ich sąsiedztwie poprzez obserwacje i badania ankietowe. Określili na ich podstawie częstotliwość i przyczyny korzystania łodzian z obszarów rekreacyjnych. Przedstawiono ocenę mieszkańców użytkowanych przez 
nich terenów oraz proponowane na nich zmiany w zakresie infrastruktury. Wśród klasyfikacji obszarów rekreacyjnych, zaproponowanych przez autorów wspomnianej publikacji, interesujące $\mathrm{w}$ świetle niniejszego artykułu są dwa ich rodzaje: parki miejskie oraz Las Łagiewnicki jako osobna kategoria. W ramach badań nad parkami miejskimi można odnaleźć informacje na temat Górki Widzewskiej oraz górki w parku im. M. Zaruskiego. Dowiemy się m.in. że jedynym parkiem miejskim posiadającym ścieżkę zdrowia jest Górka Widzewska. Dość oczywiste okazały się motywy odwiedzania terenów rekreacyjnych przez respondentów, gdzie Las Łagiewnicki wybierano kierując się jego walorami naturalnymi, a Górkę Widzewską ze względu na bliskość miejsca zamieszkania (JAKÓBCZYK-GRYSZKIEWICZ i in. 2008).

Według E. SZAFRAŃSKIEJ (2012) park Górka Widzewska jest przykładem przekształcenia terenu niezagospodarowanego $\mathrm{w}$ zieleń osiedlową $\mathrm{z}$ powodu zmian przestrzenno-funkcjonalnych osiedla Widzew-Wschód. Autorka opisuje szczegółowo etapy powstawania parku podkreślając, że ma on dużą wartość rekreacyjno-wypoczynkową dla mieszkańców osiedla. Wspomina również o nagrodzie Towarzystwa Urbanistów Polskich, którą park otrzymał w 2004 r. jako najlepiej zagospodarowana przestrzeń publiczna województwa łódzkiego.

A. NIEWIADOMSKI (2013) zwraca uwagę, że Las Łagiewnicki oprócz znaczenia rekreacyjnego pełni funkcje komunalne i ochronne (istnienie rezerwatu leśnego). Autor zaznacza jeszcze, że łódzki las o powierzchni 1205 ha jest jednym $\mathrm{z}$ największych miejskich kompleksów leśnych w Europie. Jako pozytywne zjawisko przedstawiono coraz większe zainteresowanie pozyskiwaniem środków finansowych na rewitalizację i rewaloryzację terenów zielonych, tak jak np. na edukację ekologiczną w Lesie Łagiewnickim.

Kompleks leśny Łagiewniki wraz z innymi lasami tworzy największą powierzchniowo grupę, która odgrywa najistotniejszą rolę $\mathrm{w}$ funkcjonowaniu systemu przyrodniczego Łodzi (Studium uwarunkowań $i$ kierunków zagospodarowania przestrzennego miasta Łodzi 2010).

\section{METODOLOGIA ORAZ WYNIKI BADAŃ TERENOWYCH}

W niniejszej pracy wykorzystano inwentaryzację oraz badanie sondażowe. Inwentaryzacja fotograficzna w ujęciu statycznym polegała na sporządzaniu rejestru fotograficznego obiektów. Ankieta audytoryjna była wręczana do samodzielnego wypełnienia grupie osób zgromadzonych w jednym miejscu, następnie zbierana przez upoważnioną osobę, która w trakcie trwania badania może udzielać dodatkowych wy- jaśnień związanych z prawidłowym wypełnieniem ankiety. Autorzy zdecydowali się na sondaż ankietowy, albowiem dostarcza on wielu zmiennych do analizy w krótkim czasie, a jego wyniki moga posłużyć do sformułowania twierdzeń opisowych o grupie badanych (BABBIE 2003). Na potrzeby artykułu w badaniach inwentaryzacyjnych uwzględniono wzniesienia o wysokości ponad $200 \mathrm{~m}$ n.p.m. Wzniesienia, przez które przechodzi droga publiczna lub występuje zabudowa mieszkalna, zostały odrzucone w dalszych badaniach jako tereny niemożliwe do wykorzystania dla rekreacji.

Inwentaryzacja fotograficzna została przeprowadzona przez autorów w marcu i w maju 2017 r. na terenach: Rudzkiej Góry, Górki Rogowskiej, parku im. M. Zaruskiego, parku Widzewska Górka oraz w Lesie Łagiewnickim. Miała ona na celu zwrócenie uwagi na aktualny stan zagospodarowania rekreacyjnego wzniesień, a także zaobserwowanie, czy łódzkie wzniesienia są wykorzystywane rekreacyjnie przez mieszkańców Łodzi. Metodą badawczą, którą się posłużono była inwentaryzacja fotograficzna wykonana za pomoca smartfonów wyposażonych $\mathrm{w}$ aparaty fotograficzne. Wykonane zdjęcia wzniesień łódzkich zostały umieszczone na karcie inwentaryzacyjnej wraz z mapą z oznaczonymi miejscami i kierunkami wykonywania zdjęć.

Pierwsza karta inwentaryzacji fotograficznej pochodzi z 25.03.2017 r. i dotyczy Rudzkiej Góry znajdującej się przy ulicy Starorudzkiej w Łodzi. Jest to częściowo sztucznie usypane wzniesienie o wysokości 230 m n.p.m., zaś jej naturalny fragment to pozostałość polodowcowa. Na terenie Rudzkiej Góry znajduje się tor saneczkowy, trasy rowerowe do uprawiania m.in cross country czy "downhillu” (jedna z ekstremalnych odmian kolarstwa górskiego), a także zaniedbana skocznia narciarska K-15. Ponadto od 2002 r. dostępna jest góralska bacówka, w której znajduje się restauracja. Po przeprowadzeniu inwentaryzacji fotograficznej i na podstawie własnych obserwacji autorzy zwrócili uwagę na pewne braki infrastruktury. Przede wszystkim na terenie Rudzkiej Góry nie ma wybrukowanej ścieżki, która umożliwiłaby wejście na szczyt osobom starszym, niepełnosprawnym czy też rodzinom z dziećmi. Wszystkie ścieżki, które znajdują się na terenie wzniesienia są "dzikie”, wydeptane przez użytkowników i w większości zarośnięte dziką roślinnością. Ponadto brakuje wyznaczonej trasy dla rowerzystów oraz pieszych, co sprawia, że osoby spacerujące narażają się na niebezpieczeństwo przechodząc przez miejsca, w których trenują rowerzyści uprawiający wspomniany cross country czy downhill. Na Rudzkiej Górze zauważono także deficyt koszy na śmieci, czego skutkiem są porozrzucane odpadki. Dużym mankamentem jest brak lawek, przez co mieszkańcy nie mają gdzie odpocząć. Wśród istniejących elemen- 
tów zagospodarowania rekreacyjnego można wymienić skocznię narciarską K-15 (porośniętą roślinnością) i tor saneczkowy, który jako jedyny nadaje się do korzystania ze względu na jego dobry stan techniczny. Niemniej jednak z obserwacji wynikło, że ludzie przychodzili na Rudzką Górę, następnie zjeżdżali po torze saneczkowym, po czym opuszczali teren wzniesienia. Świadczy to ewidentnie o zbyt skromnym zagospodarowaniu rekreacyjnym tego obszaru.

Druga inwentaryzacja fotograficzna dotyczyła wzniesienia mierzącego 245 m n.p.m. znajdującego się na terenie parku Górka Widzewska pomiędzy ulicami Milionową, Czernika, Bartoka oraz aleją Przyjaźni. Inwentaryzacja przeprowadzona została przez jedna ze studentek 14 maja 2017 r. Obszar, na którym obecnie mieści się park dawniej był zwałowiskiem śmieci z okolicznych placów budowy, które zostało zasypane ziemią. Sam park Górka Widzewska powstał z inicjatywy społecznej rady osiedla w 2001 r. Na terenie parku wytyczone są ścieżki rowerowe i oznakowane ścieżki piesze, w dużej liczbie znajdują się również ławki i kosze na śmieci. Z elementów zagospodarowania rekreacyjnego zinwentaryzowano siłownię na powietrzu, stoły do gry w szachy, plac zabaw, a także boiska wielofunkcyjne na terenie Szkoły Podstawowej nr 199, zlokalizowanej w pobliżu parku. Na terenie parku dominantami są dwa wzniesienia, które połączono 26-metrowym mostkiem. Warto dodać, że obszar ten jest zadbany, a mieszkańcy chętnie $\mathrm{z}$ niego korzystają. Podczas przeprowadzania obserwacji stwierdzono, że najwięcej osób znajdujących się na terenie wzniesienia spaceruje, jeździ na rowerze, odpoczywa na trawie, a także biega. W zagospodarowaniu nie zarejestrowano braków, jednakże autorzy uważają, że na tym obszarze mogłyby pojawić się pewne elementy, np. leżaki, tyrolka, wypożyczalnia sprzętu sportowego, lunety obserwacyjne, które uatrakcyjniłyby wypoczynek na wzniesieniu.

Trzecia inwentaryzacja przeprowadzona została 16.05.2017 r. na terenie parku im. gen. M. Zaruskiego na osiedlu Stoki, gdzie najwyższe wzniesienie osiąga 272 m n.p.m. Park utworzono w 1954 r., a jego elementem charakterystycznym jest duże zróżnicowanie wysokości. Deniwelacja wynosi prawie $20 \mathrm{~m}$, a teren unosi się w kierunku północno-wschodnim, do wysokości ponad $270 \mathrm{~m}$ n.p.m. Jest to kolejny przykład sztucznego wzniesienia, ponieważ dawniej podczas budowy okolicznych osiedli mieściła się tam żwirownia, którą następnie zasypano ziemią. Na terenie parku powstał plac zabaw, siłownia na powietrzu, oprócz tego wybrukowano ścieżki, wzdłuż których ustawiono (średnio co $5 \mathrm{~m}$ ) ławki i kosze na śmieci. Niemniej jednak autorzy dostrzegli, że w okolicy wzniesienia i na jego terenie brak jakichkolwiek mebli miejskich (stojaki na rowery, ławki, kosze na śmieci) oraz urządzeń, które uatrakcyjniłyby wypoczywającym tę prze- strzeń jeszcze bardziej. Zaobserwowano, że użytkownicy jedynie leżą na kocach na wzniesieniu lub spacerują z psami. W opinii autorów obszar ten mógłby być wykorzystany jako miejsce pikników, gdyby zamontowano odpowiedni sprzęt. Mogłaby powstać tzw. wioska hamakowa, która byłaby nowoczesnym miejscem biernego odpoczynku, wykorzystującym duży potencjał obszaru.

Kolejna inwentaryzacja miała miejsce również 16.05.2017 r. na Górce Rogowskiej, zwanej Śmieciową, zlokalizowanej przy ulicy Łupkowej. Na terenie wzniesienia mieściło się wysypisko śmieci i odpadów budowlanych, a obecnie znajduje się tam punkt widokowy na wysokości 268 m n.p.m. Oceniając zagospodarowanie rekreacyjne stwierdzono, że oprócz ścieżki nie zauważono nic więcej. Wzniesienie pomimo swojej atrakcyjności i potencjału nie zostało zagospodarowane $\mathrm{z}$ myślą o mieszkańcach. Brakuje podstawowych elementów zagospodarowania, takich jak: ławki, kosze na śmieci, podjazd dla osób niepełnosprawnych czy barierki bezpieczeństwa. Podczas gdy w źródłach internetowych Górka Śmieciowa uchodzi za punkt widokowy, to w rzeczywistości nic na to nie wskazuje. Wzniesienie zarosła dzika roślinność utrudniająca podziwianie panoramy miasta. Obecny stan sprawia, że miejsce to jest całkowicie nieatrakcyjne zarówno dla turystów, jak i dla mieszkańców.

Ostatnia inwentaryzacja została przeprowadzona 17.05.2017 r. na terenie Lasu Łagiewnickiego, w którym występują wzniesienia mierzące od 215 do $260 \mathrm{~m}$ n.p.m. „W roku 1996 prawie cały kompleks wszedł w skład Parku Krajobrazowego Wzniesień Łódzkich rozciągającego się pomiędzy Łodzią, Strykowem i Brzezinami" (MAĆKOWIAK 2004). Górki w Lesie Łagiewnickim zagospodarowane są głównie przez rowerzystów - w sposób nieoficjalny. Trasy i skocznie rowerowe zrobione są przez społeczność rowerową najprawdopodobniej bez żadnej kontroli. Na górkach powstaja tzw. single tracki, czyli pojedyncze trasy zjazdowe. Wyglądają one naturalnie, usypane są z ziemi i wzmocnione drewnem, przez co nie sprawiają wrażenia ingerencji w naturalny kompleks leśny. Przydatnym zagospodarowaniem byłoby unormowanie tras, objecie ich oficjalnym nadzorem $\mathrm{w}$ celu poprawienia ich stanu technicznego i bezpieczeństwa, a także oznaczenie tras rowerowych oraz naniesienie ich na plan zagospodarowania lasu. Ze względu na specyfikę terenu autorzy zauważają, że nie ma potrzeby powiększania infrastruktury rekreacyjnej. Obecny stan zagospodarowania jest optymalny i różnorodny, począwszy od ścieżek szlaku konnego, a na ośrodkach rekreacyjnych skończywszy.

Druga część badań obejmowała przeprowadzenie ankiety audytoryjnej na przełomie kwietnia i maja 2017 r. ze studentami kierunku "turystyka i rekreacja” na Uniwersytecie Łódzkim. Spośród 364 studiujących 
na tym kierunku w badaniach wzięło udział 135 osób, co stanowi 37\% badanej zbiorowości. Ankieta składała się z czterech pytań dotyczących miejsca zamieszkania, uczęszczania na wzniesienia znajdujące się w Łodzi, form rekreacji uprawianych na danym wzniesieniu, częstotliwości odwiedzania „łódzkich gór”. Na końcu zamieszczona została krótka metryczka.

Analizując strukturę społeczno-demograficzną respondentów można zauważyć, że liczba kobiet była znacznie większa niż liczba mężczyzn. W badaniach wzięło udział 99 kobiet oraz 36 mężczyzn, co stanowi odpowiednio $73 \%$ oraz $27 \%$ badanych. Najwięcej osób, bo aż 62, deklarowało przedział wieku od 21 do 22 lat, następnie było 39 osób w wieku 19-20 oraz 39 studentów z przedziału wiekowego 23-24. Najmniej respondentów miało ukończone 25 i 26 lat - zaledwie dwie osoby. Wśród ankietowanych nie było osób mających powyżej 26. roku życia (rys. 1).
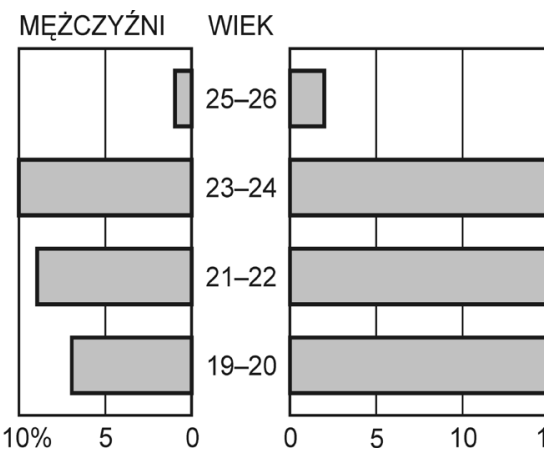

Rys. 1. Piramida wieku i płci respondentów wypoczywających na łódzkich wzniesieniach

Źródło: opracowanie własne na podstawie badań terenowych

Następnie respondenci proszeni byli o zaznaczenie tych spośród wymienionych wzniesień w Łodzi, na które uczęszczają. Spośród 135 badanych jedynie 45 osób nie znało żadnego wzniesienia. Najwięcej badanych (24\%) wskazało wzniesienia w Lesie Łagiewnickim, drugą najczęstszą odpowiedzią była Rudzka Góra (23\%), a na trzecim miejscu ex aequo Górka Widzewska (park) oraz Górka Retkińska uzyskujące po 13\% udzielonych odpowiedzi. Najmniej uczęszczanymi wzniesieniami był park im. gen. M. Zaruskiego (4\%) i Górka Józefowska (3\%), co przedstawia rys. 2.

Kolejne pytanie dotyczyło częstotliwości uczęszczania na wskazane wcześniej wzniesienia. W ten sposób zamierzano dowiedzieć się, czy respondenci odwiedzają wzniesienia sporadycznie czy też regularnie. Najwięcej respondentów regularnie odwiedza Górkę Rogowską, znaną jako Śmieciowa - aż 26\% osób wskazało taką odpowiedź. Najmniej ankietowanych regularnie uczęszcza na wzniesienia na Rudzie Pabianickiej (zaledwie 7\%). Struktura odpowiedzi została przedstawiona na rys. 3 .

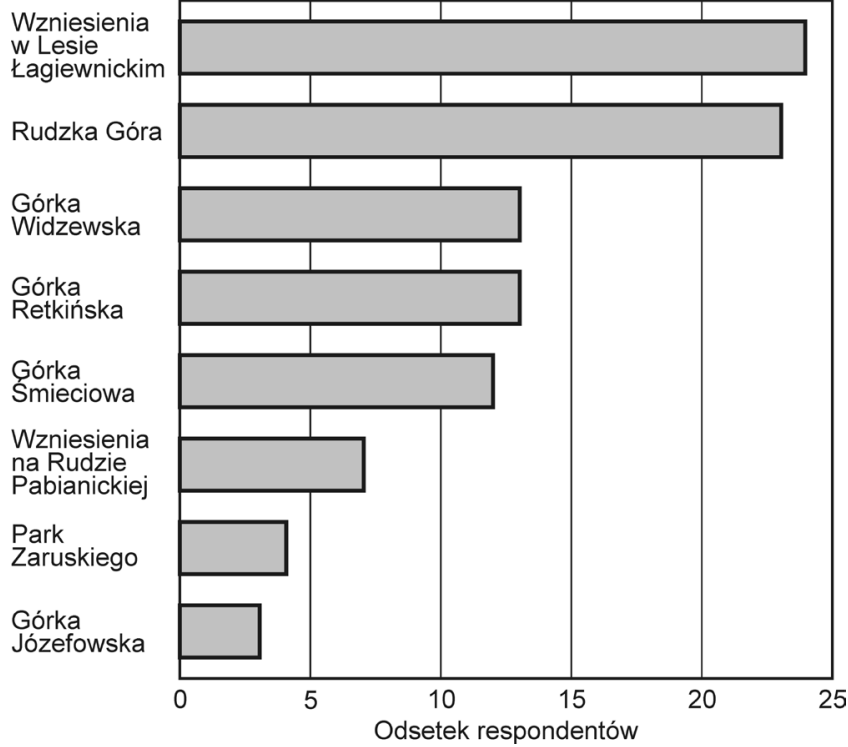

Rys. 2. Uczęszczane wzniesienia łódzkie przez respondentów Źródło: opracowanie własne na podstawie badań terenowych

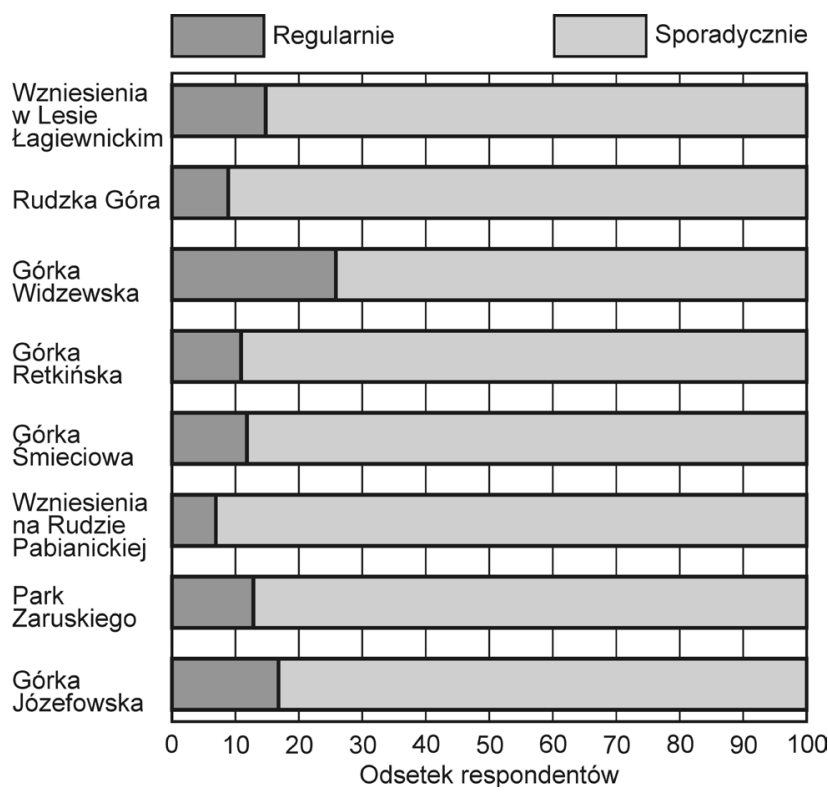

Rys. 3. Częstotliwość odwiedzin wzniesień łódzkich przez respondentów

Źródło: opracowanie własne na podstawie badań terenowych

Następne pytanie dotyczyło form rekreacji, jakie respondenci uprawiają będąc na wskazanym wcześniej wzniesieniu. Strukturę odpowiedzi prezentuje tab. 1.

Najwięcej respondentów będąc na wzniesieniu spaceruje bądź jeździ na rowerze. Co ciekawe, spośród ośmiu wzniesień tylko na jednym $z$ nich, tj. na Górce Śmieciowej badani nie wskazali odpowiedzi „bieganie". W przypadku uprawiania sportów zimowych popularnymi łódzkimi "górami" są wzniesienia w Lesie Łagiewnickim oraz Rudzka Góra, na których 
Tab. 1. Formy rekreacji uprawiane na wzniesieniach łódzkich wskazane przez respondentów (\% odpowiedzi)

\begin{tabular}{|c|c|c|c|c|c|c|}
\hline \multirow[b]{2}{*}{ Wzniesienie } & \multicolumn{6}{|c|}{ Forma aktywności } \\
\hline & bieganie & spacerowanie & $\begin{array}{l}\text { jazda na } \\
\text { rowerze }\end{array}$ & $\begin{array}{c}\text { jazda na } \\
\text { nartach }\end{array}$ & $\begin{array}{l}\text { zjeżdżanie } \\
\text { na sankach }\end{array}$ & inne \\
\hline Wzniesienia w Lesie Łagiewnickim & 13 & 60 & 22 & 2 & 3 & 0 \\
\hline Wzniesienia na Rudzie Pabianickiej & 7 & 65 & 21 & 0 & 7 & 0 \\
\hline Park Zaruskiego & 17 & 50 & 17 & 0 & 17 & 4 \\
\hline Górka Widzewska & 14 & 50 & 11 & 0 & 25 & 0 \\
\hline Górka Józefowska & 17 & 50 & 33 & 0 & 0 & 0 \\
\hline Górka Śmieciowa & 0 & 66 & 26 & 0 & 4 & 0 \\
\hline Górka Retkińska & 6 & 62 & 20 & 0 & 12 & 0 \\
\hline Rudzka Góra & 4 & 50 & 16 & 2 & 28 & 0 \\
\hline
\end{tabular}

Źródło: opracowanie własne na podstawie badań terenowych.

ankietowani jeździli na nartach, zaś na pozostałych popularnymi odpowiedziami było zjeżdżanie na sankach (oprócz Górki Józefowskiej). Jeden ankietowany wskazał odpowiedź „inne”, podając dyscyplinę off-road (z ang. poza droga); jest to „sport motorowy polegający na jeżdżeniu specjalnie przygotowanym samochodem" (www.turystyka4x4.pl), który uprawiał na Górce Śmieciowej.

\section{WNIOSKI}

Po przeprowadzonych badaniach oraz analizie literatury autorzy są zgodni, że zagospodarowanie rekreacyjne terenów zielonych, w tym szczególnie wzniesień łódzkich, jest niewystarczające. Najczęściej górki miejskie uczęszczane są przez mieszkańców najbliższych i okolicznych osiedli. Inwentaryzacja wzniesień pozwoliła określić stan aktualnego zagospodarowania, uściślając braki w infrastrukturze oraz możliwości rozwoju badanych terenów. Niewykorzystanie w pełni łódzkich wzniesień związane jest ze skromnym stanem infrastruktury oraz nieznajomością wzniesień przez mieszkańców. Przeprowadzone badania ankietowe miały na celu próbę odpowiedzi na jedno $z$ trzech pytań pomocniczych dotyczące znajomości „łódzkich gór" wśród studentów turystyki i rekreacji Uniwersytetu Łódzkiego. Z uzyskanych odpowiedzi wynika, że prawie $70 \%$ ankietowanych uczęszcza na wzniesienia znajdujące się na terenie Łodzi. Każdorazowo podczas pobytu na górce podejmowane są różne formy rekreacji ruchowej.
Badanie ankietowe wykazało, że są osoby od urodzenia mieszkające w Łodzi, które nie były nigdy na żadnym wzniesieniu miejskim. Uzasadnienia tego stanu rzeczy można doszukiwać się w różnych zainteresowaniach studentów. Autorzy zauważyli także, że osoby bardziej aktywne lub uprawiające jakiśs sport wykazywały się na ogół lepszą znajomością „łódzkich gór".

\section{BIBLIOGRAFIA}

BABBIE E., 2003, Badania spoteczne w praktyce, Wyd. Naukowe PWN, Warszawa.

JAKÓBCZYK-GRYSZKIEWICZ J., DYBA W., MARCIŃCZAK SZ., TANAŚ S., 2008, Zagospodarowanie terenów rekreacyjnych Łodzi. Plan, perspektywoy, Łódzkie Towarzystwo Naukowe, Łódź.

MAĆKOWIAK T., 2004, Łagiewniki tódzkie - przewodnik, Wyd. Literatura, Łódź.

NIEWIADOMSKI A., 2013, Struktura i znaczenie terenów zieleni w Łodzi na tle dużych ośrodków miejskich w Polsce, "Acta Universitatis Lodziensis. Folia Geographica Physica", 12.

Studium uwarunkowań $i$ kierunków zagospodarowania przestrzennego miasta Łodzi, 2010, Uchwała nr XCIX/1826/10 Rady Miejskiej w Łodzi z 27 października $2010 \mathrm{r}$.

SZAFRAŃSKA E., 2012, Przemiany struktury spotecznej, przestrzennej i funkcjonalnej wielkich osiedli mieszkaniowych na przyktadzie osiedla Widzew-Wschód w Łodzi, [w:] J. Dzieciuchowicz, L. Groeger (red.), Ksztattowanie przestrzeni mieszkaniowej miast, „,Space - Society - Economy", 11, Wyd. Uniwersytetu Łódzkiego, Łódź, s. 179-195.

www.czasatrakcji.pl.

www.parki.org.pl.

www.pl.cit.lodz.pl.

www.turystyka4x4.pl.

www.wikiepdia.pl. www.zielonalodz.info. 
